\title{
Modeling of information on the impact of mining exploitation on bridge objects in BIM
}

\author{
Piotr Bętkowski ${ }^{1, *}$, \\ ${ }^{1}$ Silesian University of Technology, Faculty of Civil Engineering, Department of Mechanics \\ and Bridges, Gliwice, Poland
}

\begin{abstract}
The article discusses the advantages of BIM (Building Information Modeling) technology in the management of bridge infrastructure on mining areas. The article shows the problems with information flow in the case of bridge objects located on mining areas and the advantages of proper information management, e.g. the possibility of automatic monitoring of structures, improvement of safety, optimization of maintenance activities, cost reduction of damage removal and preventive actions, improvement of atmosphere for mining exploitation, improvement of the relationship between the manager of the bridge and the mine. Traditional model of managing bridge objects on mining areas has many disadvantages, which are discussed in this article. These disadvantages include among others: duplication of information about the object, lack of correlation in investments due to lack of information flow between bridge manager and mine, limited assessment possibilities of damage propagation on technical condition and construction resistance to mining influences.
\end{abstract}

Keywords: BIM, mining damages, bridges, management, maintenance

\section{Introduction}

Traditional model of managing bridge infrastructure on mining areas has many disadvantages, which are discussed below in a few next points. Basic problem is the lack of proper connection of many information related to the bridge objects and the lack of information flow between entities interested in maintaining the bridge properly (e.g. road manager, local mine, commune/city office, technical infrastructure administrators).

In Poland and in many other countries methods of modeling information about building objects, know under common password BIM (Building Information Modeling) are widely popular [e.g. 1 $\div 5$ ]. The application of BIM or the implementation of some of the assumptions are mandatory (i.e. required by law) e.g. in Great Britain, USA, Norway, Denmark, Singapore. In Poland several BIM pilot projects in the field of design, construction and maintenance of bridges are implemented and are being implemented.

*Corresponding author: piotr.betkowski@pols1.pl 
In the next few years, BIM will be gradually introduced in all countries associated in the European Union, in accordance with the requirements of the European Directive 2014/24/EU announced in February 2014 on competitive tendering. In the first place, BIM will include public investments, and thus bridge objects. Regardless of law regulations imposed, BIM is a very efficient method of information modeling, allowing optimizing management activities throughout the entire life cycle of bridges. BIM technology can be implemented for mining damages, using available methods, algorithms and software. The article discusses the advantages of BIM technology in relation to bridge objects located on mining areas. It is shown how the correct modeling of information about the object helps to reduce mine costs related to the removal of mine damages and protection of objects against mining influences and reduces the costs of administration relate to the maintenance of the objects. Other advantages of having a common advanced BIM model of the bridge are also presented, such as the possibility of remote monitoring, improvement of safety, coordination of mining operations and managing of the bridge objects in the field of renovation and modernization, improvement of the relationships among the bridge manager, coal mine and local commune/city office.

\section{Basic problems related to bridges on mining areas}

Administrators of roads generally do not have full information about the impact of mining deformations on bridge objects over time, e.g. deformation indicators (horizontal strains $\varepsilon$, etc.) for every months or the continuous function of settlements $w$, but only the end values of indicators at the end of a certain period of time (e.g. the Three Years' Mine Exploitation Plan). The inability controlling the growth of deformation causes distrust to mines and makes difficult the proper supervision of the object, e.g. during the appearance of mining influences on the surface of the area.

Mines have a little knowledge about the construction of bridges and investment plans of Road Administration. In areas of mining influences, certain information should be available for mines; such data could be helpful in planning coal mining exploitation in a given mining wall over time, in activities related to removal of mining damages and mining prevention. Due to the improper information flow, the mines many times prepared the documentation of removal mining damages and adaptation of the structures to taking over future mining influences for objects planned to replacement by the Administrator due to insufficient load capacity or insufficient gauge. In many cases, the object from an economic point of view could be protected for a shorter period of time with only significant damages removed, if, for example, the rebuilding is planned by the Administrator in three years.

The static and dynamic resistance of the bridge objects to mining influences depend on its technical conditions and kinematic capabilities. Mines make the assessment of the resistance of objects to mining influences once every three years as part of so-called Mine Exploitation Plan. During that time, several mining walls may be exploited in the area of the bridge, and damages may occur in the object - that reduces resistance to mining influences, e.g. significant cracks in the zone of joining the pillars and spans in the frame constructions [6,7]. The static and dynamic resistance of bridge structures to mining influences is not constant, but changes in time. The assessment of the technical condition is, in the case of mining areas, also the assessment of damage propagation and the assessment of the impact of damages on the "work" of the structure. Using BIM, damages can be easily taken into account in the bridge model and updated if necessary.

Using tools and technologies that are easily combined with BIM, such as e.g. AR (Augmented Reality), we can overlap the images from the last and current bridge review (tablet, projection glasses) during visit on the object, which allows quickly and reliably control critical sections directly on the real construction (e.g. $[4,5])$. 
The article shows the problems with information flow in the case of bridge objects located on mining areas and indicates the benefits of advanced information models (BIM), e.g. the possibility of automatic monitoring of structures, improvement of safety, optimization of maintenance activities (e.g. repairs) by time and scope (cost reduction). Bridge objects management can be understood as combination of all technical, administrative and management activities of the life cycle after the completion of the construction of the object.

\section{BIM as information model}

At present, flat 2D drawings dominate in relation to bridge infrastructure in mining areas (e.g. $[6 \div 13]$ ) and popular are mathematical formulas given by professor Rosikoń [14]. More possibilities are given by use of 3D spatial model, extended by additional parameters, so that the rotations and displacements of spans and bridgeheads can be modeled as rigid solids [15]. Spatial models of the objects and deformations allow directly on include information from monitoring systems into the bridge models and using measurements from various sources and methods. Efficient tools are provided by BIM technology $[1 \div 5]$. By supplementing the 3D BIM model with additional parameters, we can quickly obtain the 4D model (work schedule) and 5D (investment cost). In this way it is easy to analyze and compare cost-effectiveness and organisation of several repair solutions (currently technical-economic comparisons are rarely carried out). BIM 6D enables quick realization of accurate energy analyzes for buildings, but bridges do not required such analyzes. BIM 7D is used by managers in the process of managing the building objects at the stage of its exploitation. BIM tools allow on describing in a certain period of time/future, the investment plans of the bridge objects manager and planes activities of the mine in the scope of damage repair and prevention, in such case the correlation of investments is easier.

BIM technology is a process, during which a model common for all industries is created. This model combines additional information related to the individual elements of bridge (e.g. expansion joints, bridge bearings). In such process, a number of additional parameters may be included such as, for example, results of geodetic measurements, data from automate measurement (monitoring) systems and other technical information needed by each of the participants (e.g. investment plans of the bridge administration, activities planned by the local mine). All information that are included in this model can be used by all participants, such as the bridge administration, local commune or city, local mine, technical infrastructure administrators running after (under) the bridge (e.g. waterworks, gas pipeline, power cables) or an institution responsible for water management in the case of watercourses. When talking about the process, we should keep in mind the organization of flow of information in the amount needed by each participant.

The traditional model of managing bridge infrastructure on mining areas is inefficient, it is necessary to contact each participant with each other, in order to obtain information (Fig. 1.). Moreover each participant may have different information, often out of date. These disadvantages cause distrusts between the bridge administration, the mines and the local self-government units. These disadvantages make also difficult planning of exploitation of coal deposits in the area of the bridge, negatively affect on safety and comfort of use, and increase the cost of maintaining objects and the removal of damages.

BIM is a technology based on a common model to which all participants of the process can access in real time (Fig. 2.). The model works properly if all participants update the data which they have provided to the model. Participants can expand the model with additional data at any time. Interoperability of participant's technology platforms is important here, i.e. providing data in a form that all participants can use. It is necessary to 
standardize the procedures and details of the model, e.g. marking and description of layers, because all participants of the process have access to the same model. Ready solutions in the field of cooperation (interoperability) are provided by, for example, the British family of BS 1192 standards, defining the framework of BIM processes.

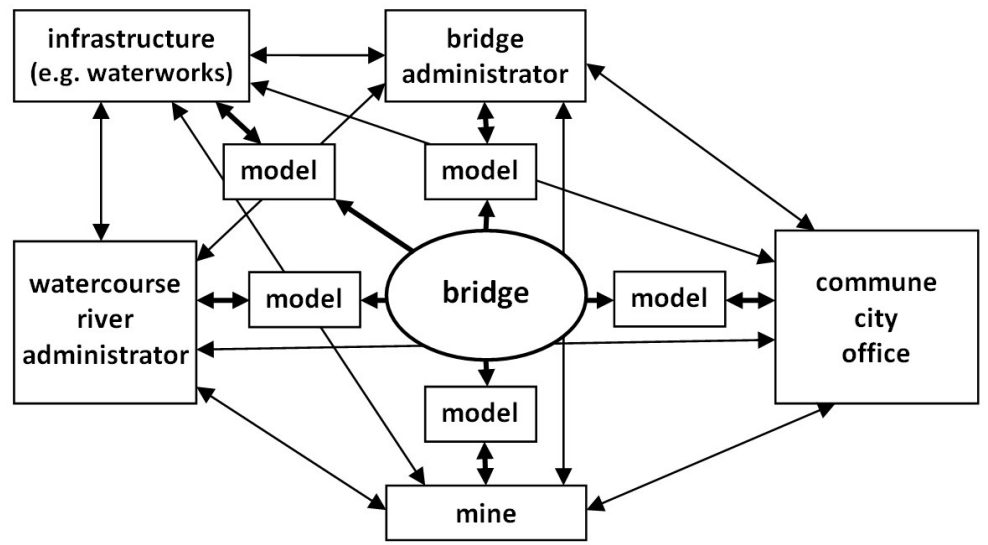

Fig. 1. Traditional model of information flow (bridge object on the mining area).

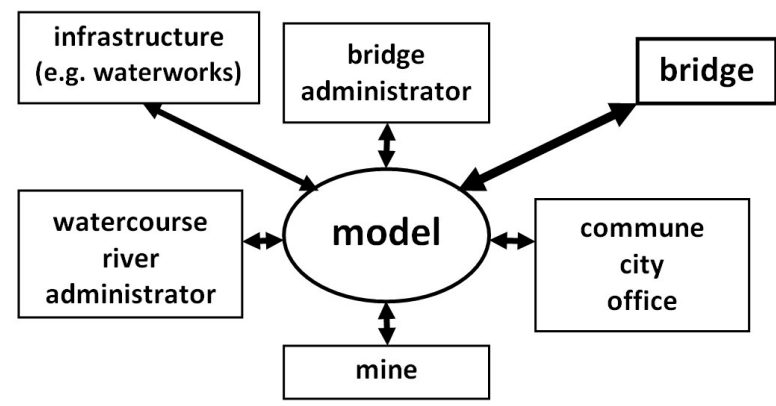

Fig. 2. BIM model of information flow (bridge object on the mining area).

\section{Duplication of information about the bridge object}

Every three years, in the scope of Mine Exploitation Plan, each of the mines performs documentation containing the assessment of static and dynamic resistance to mining influences of all bridge structures located in its mining area, which are located in the reach of the planned mining exploitation. The contractor for such elaboration is selected in the open tender. Practically every time, the bridge geometry and the damages of structure are inventoried. In the case of BIM technology, the model of the bridge with current structural damages would be available for downloading, so the workload for such assessment would drop by more than $50 \%$ (the major part of the documentation are the same information obtained all over again by another company). In addition, it would be possible to analyze the propagation of damage over time (e.g. indication of active cracks, etc.), so the quality of the documentation would be significantly improved.

Documentation of mining damage removal and protection against the projected mining influences is performed if the object is not able to take over the predicted mining impacts or there are any significant damages of the structure, reducing its load capacity and/or resistance to mining influences. A significant part of such project is doubled with the 
above-mentioned resistance assessment. A designer of renovation/reconstruction must therefore obtain a lot of the same information. BIM technology would provide ready digital bridge model for such the designer. After the completion of the project, the designer should provide data for updating the BIM model on a common platform (i.e. the model available to all participants of the process). Visit on the bridge object can be used in this case to validate the BIM model. The digital bridge model can be quickly implemented into new analyzes, what significantly reduces the necessary time and cost of analytical calculations and reduces the risk of errors.

\section{Incorrect correlations in investments}

The mine orders making a design documentations regarding on elimination of mining damages and preventive actions and provides reconciliation of this documentations by bridge administrator/owner. Unfortunately, in many cases, bridge administrators do not inform local mines about activities in the future regarding to the object, e.g. replacement or significant reconstruction of the bridge object in the near future. In BIM, data on investment plans of managers/administrators of bridges or watercourses as well as planned activities by mines in the field of road and rail infrastructure could be described on the timeline as an additional parameter. Some examples of the lack of correlations in investments are provided below.

Three-span bridge frame has been protected against mining influences for the entire estimated mining exploitation, i.e. for about 20 years. The mine incurred significant costs. Three years after renovation, the bridge's administrator decided to demolish the object and build a new one due to insufficient load-bearing capacity of the structure and insufficient width in relation to the parameters of the modernized road [6, 7].

Mine repaired the railway viaduct in December, and in June of the following year, the corroded spans of this viaduct were replaced with new ones, and the abutments and pillars partially demolished and seriously rebuilt as part of the revitalization this PKP line [16].

Mine wanted to liquidate floodplains formed on the river as a result of the area subsidence and commissioned making documentation which allow on lowering the river bed to a specified level. It was necessary, among others, to protect the foundations against undercutting by river, as well as pillars and abutments against the loss of stability in the case of four bridges [10]. It was necessary to correct the shoreline. It took about two years to make this documentation. Documentation ultimately was not sent for implementation, because on the request of the watercourse administrator, a project to strengthen the river bed on the $500 \mathrm{~m}$ section at the connection of the river and the local stream was initiated, so that to prevent flooding and silt up bottom - this watercourse administrator project was part of a larger task where a large EU subsidy was obtained (the change in the "EU" project threatened to return the subsidy for the entire task) [10].

\section{Technical conditions and resistance to mining influences}

Static and dynamic resistance of bridge structures to mining influences is not constant, but changes over time. Mining exploitation has a significant impact, e.g. by stretching/squeezing expansion joints, introducing significant displacements into bearings $[9,12,13,14,15,16,17]$. The mining turning and tilting of abutments may lead to cracking on the abutments and spans $[5,6,9,11,12,14,15]$. The change in the curvature of the area has a negative effect on the construction of abutments - significant cracks may be created that destroy the integrity of the solid of bridgehead $[8,9,11,12,15]$. The uneven support subsidence, associated with the curvature, generates additional internal forces in continuous 
multi-span structures $[6,7]$. In hyper static structures (e.g. multi-span continuous beams, frames), appears scratches which can develop into significant cracks $[6,7,8,9,12]$.

Resistance of bridge structures to mining influences also changes as a result of normal using and impact of environmental (atmospheric) factors, e.g. bearings made of steel plates may be rusty and blocked $[9,13]$.

Damage controls in traditional bridge maintenance systems are often ineffective, because such controls are usually performed too rarely and are not related to the occurrence of mining influences on the surface of the area. Bridge calculation models for assessment of resistance to mining influences are rarely verified for damages. In BIM technology, damage can be included into the model. The great advantage of BIM technology is the ability to use (in order to create, validate and update the model) many modern techniques that allow remote, automatic acquisition of information about the object, damages, displacements, e.g. by using electronic sensors, drones, satellites, cameras. Especially significant possibilities, in the case of bridge objects located on a deformed area, are given by laser scanning. Laser scanning is a technology that allows on the visualization of surrounding space by using point's cloud. Model of the object is created from the point's cloud. Laser scanning can be realized from ground (from permanent or mobile positions with a device mounted on a vehicle) or as an airborne from planes or drones.

BIM enables the use of series of advanced digital technologies to assessment of technical conditions. Augmented reality (AR) is particularly interesting in the case of mining damages [e.g. 5]. During bridge inspection operator can display damages recorded on the object during the previous inspection and compare damages on tablet (in the case of larger financial expenditures, the operator can be equipped with 3D projection glasses). By comparing images it is easier to compare damages and reliably to assess the propagation of damages - reduced are the time required for a good review and the cost of human work. In case of several bridge objects in a given mining area, bridges to frequent reviews (e.g. in case of significant mining influences or objects sensitive to mining influences), this operation (i.e. AR) may be cheaper than sending several people to describe the damages, moreover the review report is performed much faster (with less work).

\section{Acquiring information from monitoring systems}

The basic disadvantage of traditional measurements is their low frequency, generally 24 measurement cycles are carried out during the year. Rarely perform measurements do not give full information about mining influences in the area of the object - stretching and compression in many situations follow each other and partly abolish, extremes of deformation and the greatest threats often appear between measurement cycles and are not documented in any way. The results of traditional geodetic are not available in digital form, so automatically implementation of measurements in computer systems is difficult. Changes in measured quantities are manually calculated and referred to the range of bearing work at a certain point of time considered to be initial, then the displacement are calculated. The next step is to determine the displacements which will be caused by another, next mining exploitation and analyzes whether the bridge bearing will transfer these influences.

The solution to the above problems is remote, frequent measurements carry out with a certain frequency (e.g. every hour). There are several pilot remote monitoring systems installed in Poland on bridge structures on mining areas [16, 17]. Bridge administration has access to measurements perform by these systems, but the lack of appropriate digital models of bridges, force manual data processing.

The starting point during projecting of monitoring system should be real object. The parameter values measure by the system should be related to the values determined earlier on the basis of the numerical model solution and on the basis of mining prediction. The 
measurement, without comparison of the measured value, is just a simple observation. The next stage is defining the object's resistance to mining influences, e.g. analysis of: the layout and ranges of bearings, the widths of expansion joints, the width of the bearing benches. BIM technology enables the inclusion of measurement data into the model and the use this data also automatically. After defining boundary conditions for an emergency situation, the system can automatically generate warnings, which facilitate supervision of the object and directly translate into improved safety.

\section{Summary and final conclusions}

The article discusses problems related to the maintenance of bridge objects on mining areas. It is pointed out that in the field of BIM technology are currently ready solutions and tools for obtaining, modeling and managing information. Advantages of BIM technology uses to optimize the process of maintaining and managing bridges are described:

- reduction of mine costs relates to easy access to a good digital bridge model, currently identical information are obtained by different authors independently (e.g. geometric inventarisation of object, identification of bearings and material data),

- increase the quality of documents on the resistance of bridge structures to mining influences and documents related to the removal of damage and bridge protection,

- actual information about the mining influences that occurred, are occurring now and are predicted in future, related to the relevant time periods,

- information about the mining influence which bridge received and can receive in future,

- the possibility of adjusting the scope of protection solutions to mining influences and the scope of repairing works related to the removal of mining damage to the plans of the bridge administrator, reduction costs of mines,

- adaptation of investment plans (e.g. repairs, maintenance, reconstruction) to current and predicted mining exploitation and associated with it costs reduction which are bearded by the administrator of the bridge,

- avoidance of accident situations, general improvement of safety,

- increased trust between the participants of the process thanks to the transparency of each actions,

- improvement of the climate for mining exploitation in region of the object, theoretically it will be easier for mine to obtain agreement for the exploitation of larger number of coal walls, get permission for larger limit values of deformation indicators,

- the ability to control the damages development and including the damages into the digital bridge model,

- improving the quality of information about the bridge objects, its technical condition and current kinematic possibilities (e.g. ranges of bearings and expansion joints), availability and easy interpretation of the results of geodetic measurements or data from automatic monitoring systems, thanks to the connection of the measurement with the information about the object and boundary conditions of the displacements.

\section{References}

1. A. Tomana, BIM Innowacyjna technologia w budownictwie. Podstawy, standardy, narzędzia (eng. BIM. Innovative technology in construction. Basics, standards, tools). Builder, PWB MEDIA, Kraków (2016).

2. D. Kasznia, J. Magiera, P. Wierzowiecki, BIM w praktyce (eng. BIM in practice). PWN, Warszawa (2018). 
3. J.M. Davila Delgado, L.J. Butler, N. Gibbons, I. Brilakis, M.Z. Elshafie, C. Middleton, Management of structural monitoring data of bridges using BIM. In Proceedings of the Institution of Civil Engineers-Bridge Engineering, Vol. 170, No. 3, pp. 204-218, Thomas Telford Ltd, (2016, November).

4. B. McGuire, R. Atadero, C.M. Clevenger, M.E. Ozbek, Bridge Information Modeling for Inspection and Evaluation. ASCE Journal of Bridge Engineering Vol. 21 (4), 04015076, pp. 1-9, (2016).

5. M. Salamak, M. Januszka, Technologie BIM i poszerzonej rzeczywistości w inspekcji obiektów mostowych (eng. BIM and augmented reality in the inspection of bridge structures). Mosty, nr 5, pp. 28-35 (2016).

6. P. Bętkowski, S. Pradelok, M. Łupieżowiec, Maintenance and risk assessment of a concrete frame bridge impacted by mining deformations of the area. 14th Inter. Multi. Scien. GeoConfer. SGEM 2014, Conf. Proceedings, Vol. 3, pp. 345-352 (2014).

7. P. Bętkowski, S. Pradelok, M. Salamak, Concrete frame bridge impacted by mining deformations. The 9th Cent. Eur. Cong. on Concrete Engineer., pp. 192-195 (2013).

8. P. Bętkowski, Conclusions from observation the small crisp arch bridges located on mining areas. WMCAUS 2016. Procedia Engineering, vol. 161, pp. 687-692 (https://doi.org/10.1016/j.proeng.2016.08.738) (2016).

9. P. Bętkowski, Repair and protection of small railway viaduct with jammed span at the mining influence. IOP Conference Series: Materials Science and Engineering, vol. 245 022018 1757-8981, pp. 1-10 (doi: 0.1088/1757-899X/245/2/022038) (2017).

10. P. Bętkowski, Dostosowanie obiektów mostowych do obniżonego koryta rzek i potoków (eng Adapting of bridge objects to the lowered channel of rivers and streams). Przegląd Górniczy, nr 8 (70), pp. 65-70 (2014).

11. P. Bętkowski, Przebudowa i zabezpieczenie na wpływy górnicze niewielkiego wiaduktu kolejowego zintegrowanego $\mathrm{z}$ nasypem (eng. Rebuilding and protection to mining influences the small railway viaduct integrated with the embankment). Przegląd Górniczy, nr 3, pp. 1-7 (2015).

12. P. Bętkowski, Przebudowa wiaduktu kolejowego będącego pod wpływem znacznego górniczego osiadania terenu (eng Rebuilding of the railway viaduct being under the influence of considerable mining subsidence of area). Przegląd Górniczy, nr 12 (72), pp. 100-106 (2016).

13. P. Bętkowski, Wybrane problemy łożyskowania starych mostów kolejowych położonych na terenach górniczych (eng. Selected bearing problems of old railway bridges located on mining areas). Wiadomości Górnicze, nr 5, pp. 262-270 (2017).

14. A. Rosikoń, Budownictwo komunikacyjne na terenach objętych szkodami górniczymi. WKŁ, Warszawa (1979).

15. M. Salamak, Obiekty mostowe na terenach z deformującym się podłożem w świetle kinematyki brył (eng. Bridge structures located on areas with ground deformations in the light of solids konematics). Wydawnictwo Politechniki Śląskiej, Gliwice (2013).

16. P. Bętkowski, Ł. Bednarski, R. Sieńko, Structural health monitoring of a rail bridge structure impacted by mining operation. Technical Transactions Civil Engineering, 6-B (i.21), Wydawnictwo Politechniki Krakowskiej, Kraków, pp.15-27 (2014).

17. B. Parkasiewicz, M. Kadela, P. Bętkowski, R. Sieńko, Ł. Bednarski, Application of structure monitoring systems to the assessment of the behaviour of bridges in mining areas. IOP Conference Series: Materials Science and Engineering, vol. 245032018 1757-8981, pp. 1-10 (doi: 10.1088/1757-899X/245/3/032018) (2017). 